\title{
ATTITUDES OF THE TEACHER CANDIDATES OF MENTALLY HANDICAPPED CHILDREN ABOUT CHILDREN'S RIGHTS
}

\author{
Yasemin KARAMAN KEPENEKCI ${ }^{*}$ Berrin BAYDIK ${ }^{* *}$
}

\begin{abstract}
The main aim of this study is to examine the effects of variables such as gender, grade level, having taken the human rights or the children rights courses and age on the attitudes of teacher candidates of mentally handicapped children toward children rights. The second aim of the study is to determine whether these attitudes differ from those of teacher candidates of elementary school, preschool and computer and instruction technology. The study group was consisted of 85 volunteering freshman and senior students in mentally handicapped children teaching program in the Faculty of Educational Sciences at Ankara University. Also, in order to make comparisons, 202 volunteering freshman and senior students who were enrolled in undergraduate programs in elementary school teaching, preschool teaching and computer and instructional technology education at the same faculty have been included. Therefore, there were total 287 students in the study group in this research. Questionnaire for Measuring Attitudes towards Children's Rights formerly developed by Karaman Kepenekci (2006) to determine the attitudes of participants toward children's rights was used. The results have shown that gender and grade level had no effect on the attitudes of teacher candidates of mentally handicapped children toward children rights. Since none of the teacher candidates of mentally handicapped children have taken the human rights or the children rights courses, the effect of this variable on their attitudes could not be examined. No significant relation has been found between age and the attitude score of the teacher candidates of mentally handicapped children. It was concluded that the attitudes of teacher candidates of mentally handicapped children were not different from those of teacher candidates of preschool and computer and instruction technology; however, they had more negative attitudes than the teacher candidates of elementary school.
\end{abstract}

Key Words: Attitudes, teacher candidates, mentally retarded children, children's rights.

${ }^{*}$ Assoc. Prof. Dr., - Faculty of Educational Sciences, Ankara University

** Assist. Prof. Dr., - Faculty of Educational Sciences, Ankara University 


\section{SUMMARY}

The interests protected by law to allow all children to grow up in a healthy way to enjoy freedom and respect as children can be called children's rights. In Turkey, children's rights have been secured by both national and international law. The most important international document, with no doubt, is the Convention on the Rights of the Child adopted by the United Nations in 1989. This Convention also adopted by Turkey includes a total of very detailed 54 items on children's personal, political, social, and cultural rights. In the convention, all children's survival, developmental, protection and participation rights have been arranged thoroughly. In the 42th item, it has been proposed that children and adults get educated about the convention's items with proper and effective tools. In accordance with this item, all adults starting with mothers and fathers who are in an ongoing contact with children need to be educated about children's rights. It is especially important for the teachers to be educated about the children's rights. It is necessary to study the attitudes of teachers' and candidate teachers' on children's rights in order to create a database for this education. In Turkey there is no known study which examines attitudes toward children's rights of teachers or teacher candidates of mentally handicapped children. This study is motivated by this need.

The main aim of this study is to examine the effects of variables such as gender, grade level, having taken the human rights or the children rights courses and age on the attitudes of teacher candidates of mentally handicapped children toward children rights. The second aim of the study is to determine whether these attitudes differ from those of teacher candidates of elementary school, preschool and computer and instruction technology.

The study group was consisted of 85 volunteering freshman and senior students in mentally handicapped children teaching program in the Faculty of Educational Sciences at Ankara University. Also, in order to make comparisons, 202 volunteering freshman and senior students who were enrolled in undergraduate programs in elementary school teaching, preschool teaching and computer and instructional technology education at the same faculty have been included. Therefore, there were total 287 students in the study group in this research. Questionnaire for Measuring Attitudes towards Children's Rights formerly developed by Karaman Kepenekci (2006) to determine the attitudes of participants toward children's rights was used. 
The significant differences in scales of attitudes towards children by groups have been examined by using Kruskal Wallis $\mathrm{H}$ Test for Independent Samples. Kruskal Wallis H Test for Independent Samples has also been used to study the effects of gender, grade level and having taken the human rights or the children rights courses on attitude scores. In order to determine the relation between attitude scores and age, Spearman-Brown Rank Correlation Coefficient has been used. A significant level of .05 has been used.

The results have shown that gender and grade level had no effect on the attitudes of teacher candidates of mentally handicapped children toward children rights. Since none of the teacher candidates of mentally handicapped children have taken the human rights or the children rights courses, the effect of this variable on their attitudes could not be examined. No significant relation has been found between age and the attitude score of the teacher candidates of mentally handicapped children. It was concluded that the attitudes of teacher candidates of mentally handicapped children were not different from those of teacher candidates of preschool and computer and instruction technology; however, they had more negative attitudes than the teacher candidates of elementary school. In addition, the attitudes of the teacher candidates of preschool and elementary school were not different but it was shown that both the teacher candidates of preschool and elementary school had more positive attitudes than the teacher candidates of computer and instruction technology. The results illustrated that gender had no effect on the attitudes of all students who participated in the study, however grade level and having taken the human rights or the children rights courses have affected their attitudes. The students who attended fourth grade had more positive attitudes than students who attended first grade. Having taken the human rights or the children rights courses affected attitudes positively for the whole study group. For the students who have not taken the human rights or the children rights courses, it was found that the attitudes were not affected by groups, however gender had significant effect on the attitudes. The female students had more positive attitudes than male students. There was a significant negative and small relation between age and attitude towards children's rights for the whole study group. 


\section{ZİHIN ENGELLILER ÖĞRETMEN ADAYLARININ ÇOCUK HAKLARINA ILIŞKİN TUTUMLARI}

\section{Yasemin KARAMAN KEPENEKCI ${ }^{*}$ Berrin BAYDIK $^{* *}$}

ÖZ. $\mathrm{Bu}$ araştırmanın temel amacı, zihin engelliler öğretmen adaylarının çocuk haklarına ilişkin tutumlarını cinsiyete, sınıf düzeyine, insan hakları ya da çocuk haklarına ilişkin bir ders alma durumuna ve yaşa göre incelemektir. Çalışmanın ikincil amacı, zihin engelliler öğretmen adaylarının anılan tutumlarının, sınıf öğretmeni, okul öncesi öğretmeni ve bilgisayar ve öğretim teknolojileri öğretmeni adaylarının tutumlarından farklılaşıp farklılaşmadığını test etmektir. Araştırmanın çalışma grubunu Ankara Üniversitesi Eğitim Bilimleri Fakültesi’nin Zihin Engelliler Öğretmenliği lisans programı 1. ve 4. sınıflarına devam eden ve araştırmaya katılmaya istekli 85 öğrenci oluşturmuştur. Ayrıca karşılaştırma yapabilmek amacıyla, aynı Fakülte'nin 1. ve 4. Sınıflarına devam eden Sınıf Öğretmenliği, Okul Öncesi Öğretmenliği ve Bilgisayar ve Öğretim Teknolojileri Eğitimi lisans programlarına kayıtlı araştırmaya katılmaya istekli öğrenciler de (202 öğrenci) araştırma grubuna dâhil edilmiştir. Böylece araştırmanın çalışma grubunda toplam 287 öğrenci yer almıştır. Katılımcıların çocuk haklarına ilişkin tutumlarını belirlemek amacıyla daha önce Karaman Kepenekci (2006) tarafindan geliştirilen Çocuk Haklarına İlişkin Tutum Ölçeği (ÇHTÖ) kullanılmıştır. Bulgular cinsiyet ve sınıf düzeyinin zihin engelliler öğretmenliği programına kayıtlı öğrencilerin çocuk haklarına ilişkin tutumları üzerinde etkisi olmadığını göstermiştir. Zihin engelliler öğretmenliği programına kayıtlı öğrencilerinden hiçbiri insan hakları ya da çocuk haklarına ilişkin ders almadığı için bu değişkenin tutumlar üzerindeki etkisi incelenememiştir. Zihin engelliler öğretmenliği programına kayıtlı öğrencilerin tutumları ile yaşları arasında anlamlı bir ilişki bulunmamıştır. Zihin engelliler öğretmenliği programına kayıtlı öğrencilerin çocuk haklarına ilişkin tutumlarının okul öncesi öğretmeni ve bilgisayar ve öğretim teknolojileri öğretmeni adaylarının tutumlarından farklılaşmadığı, bununla birlikte bu grubun tutumlarının sınıf öğretmenliği programına kayıtlı öğrencilerin tutumlarından daha olumsuz olduğu sonucuna ulaşılmıştır.

Anahtar Sözcükler: Tutum, öğretmen adayları, zihin engelli çocuklar, çocuk hakları.

* Doç. Dr., Ankara Üniversitesi, Eğitim Bilimleri Fakültesi, ykepenekci@ hotmail.com

** Yrd. Doç. Dr., Ankara Üniversitesi, Eğitim Bilimleri Fakültesi, bbaydik@ yahoo.com 


\section{GÍRIŞ}

Eskiden gelişmemiş bir yetişkin olarak görülen çocuğa (Hart ve Pavlovic, 1991) karşı bakış açısı günümüzde değişmiş ve çocuk artık kendine özgü gereksinimleri ve hakları bulunan, korunması gerekli bir varlık olarak görülmeye başlanmıştır (Archard, 1993; Alderson, 2000; Franklin, 2001).

Bilindiği üzere, çocukluk dönemini mutlu ve sağlıklı bir şekilde geçiren bireyler, yetişkinlik döneminde de mutlu ve sağlıklı vatandaşlar olarak yaşadıkları toplumun refahına katkıda bulunurlar. Bu yüzden ülkeler maddi ve manevi olarak mutluluğa ulaşmak ve barış içinde yaşamak istiyorlarsa olanaklarının çoğunu çocukların sağlıklı büyümelerine, ilgi ve yetenekleri doğrultusunda geliştirilmelerine ayırmak zorundadırlar (Akyüz, 1999, 2000).

Çocuğun bir aile içinde doğması, büyümesi ve gelişmesi nedeniyle tarihin ilk dönemlerinden beri çocukların yetiştirilmesi ve korunması anne ve babaların ahlaki görevleri sayılmıştır. Ne var ki toplumun kalkınmasında büyük bir önem taşıyan çocuğun aile ve toplum içindeki yerinin düzenlenmesi; bedensel, zihinsel, duygusal, sosyal ve ahlaksal gelişimi ile ilgili önlemlerin alınması ve çocuğun her türlü kötü muameleye karşı korunmas1 gerekir (Burt, 1979; Lansdown, 2000). Bunlar da en etkili bir şekilde hukuk kuralları ile yapılabilir.

Zaman içinde ahlak kurallarından gelenek hukukuna doğru gelişme yaşanmasına bağlı olarak özellikle 19. yüzyıldan itibaren Avrupa'da anne babanın çocuğu yetiştirme ve koruma sorumluluğu onların hukuksal bir görevi olmuştur. Çocukların hukuksal anlamda korunması, anne-baba ve çocuklar arasındaki ilişkiler başlangıçta özel hukuk tarafindan düzenlenmiş, zamanla sadece anne-babalar değil devlet de çocuğun yetiştirilmesinde ve korunmasında sorumluluk taşımaya başlamış ve böylece çocukların hakları kamu hukuku kurallarınca da düzenlenmeye başlamıştır (Akyüz, 2000).

Yukarıdaki açıklamalar 1şı̆̆ında, tüm çocukların çocuk olmaktan kaynaklanan ve özgürlük ve saygınlık içinde, sağlıklı bir biçimde gelişebilmeleri için hukuk kuralları ile korunan yararlarına "çocuk hakları" denilebilir (Akyüz, 2000). Daha açık bir deyişle, özel hukuk, sosyal hukuk, kamu hukuku ve uluslararası hukukta yer alan kuralların çocuklara tanıdığı yetkilere çocuk hakları denir (İnan, 1968). Çocuk hakları alanında, çocukların gereksinimleri, yararları ve sahip oldukları hakların yaşama geçirilebilmesi büyük bir önem taşır (Davis ve Schwartz, 1987; Hallett, 2000; Wringe, 1985). 
Türkiye'de çocukların hakları hem ulusal hem de uluslar arası hukuk kuralları ile güvence altına alınmıştır. Ulusal hukuk kapsamında başta, 1982 Anayasasında çocuk hakları ile ilgili çeşitli hükümlere yer verildiği görülmektedir (örneğin; m. 41, 42, 50, 58, 61, 62). Bunun yanında, medeni hukuk, ceza hukuku ve iş hukuku gibi alanlara giren yasalarda da çocukların haklarının hükme bağlandığı dikkati çekmektedir.

Çocuk hakları konusu sadece ülkelerin iç hukukuna bırakılmaktan öteye geçmiş ve bu konuda uluslararası belgeler hazırlanmıştır. Bu belgelerden en önemlisi kuşkusuz Birleşmiş Milletler Genel Kurulu'nda 1989 yılında kabul edilen Çocuk Haklarına Dair Sözleşme'dir. Türkiye'nin de onayladığı bu Sözleşme'nin kapsamında çocukların kişisel, siyasal, toplumsal ve kültürel hakları ile ilgili oldukça ayrıntılı toplam 54 hüküm yer almaktadır. Sözleşme'de tüm çocukların yaşamsal, gelişimsel, korunma ve katılım hakları ayrıntılı bir şekilde düzenlenmiştir.

Osler ve Starkey'in de (1998) belirttikleri gibi, Sözleşme'de tüm çocukların yaşamsal (sağlık, beslenme, barınma vb.), gelişimsel gereksinimlerinin karşılanması (eğitim, sağlık, boş zaman vb.) ve korunmalarına (her türlü istismardan ve ihmalden korunma vb.) ilişkin hakların yanı sıra katılım haklarına (kendilerini etkileyen durumlarda düşüncelerini özgürce ifade edebilme hakk1 ve her tür bilgiyi elde etme hakk1 vb.) ilişkin maddeler de bulunmaktadır. Bu Sözleşme'de, yukarıda da belirtildiği gibi, tüm çocukların sahip olması gereken hakların yanında, başta özel gereksinimli çocuklar olmak üzere, korunmaya muhtaç çocuklar, istismar ve ihmale uğrayan çocuklar, sığınmacı çocuklar, silahlı çatışma altında bulunan çocuklar gibi özel durumdaki çocukların haklarına da yer verilmiştir. Son yıllarda özel durumdaki bu çocukların haklarını ayrı ayrı düzenleyen (Özel Gereksinimli Çocukların Hakları Sözleşmesi gibi) yeni sözleşmelerin yapılmasının gerekliliği tartışılmaktadır (Freeman, 2000).

Özellikle engelli çocuklar tarih boyunca eğitim, rehabilitasyon, uygun sağlık bakımı, oyun ya da iş firsatları ve diğer çocuklarla birlikte olma vb. haklarını kullanamamışlardır. Hatta günümüzde bazı toplumlarda, birçok engelli çocuk hala bu haklarını kullanamamaktadırlar. Diğer bir deyişle, günümüzde bazı toplumlarda engelli çocuklar temel hakları inkâr edilerek sosyal bir dışlama yaşamaktadırlar. Lundy ve Kilpatrick (2006), Çocuk Hakları Sözleşmesi'nde belirtilmesine rağmen engelli çocukların eğitimsel gereksinimlerinin yeterli bir şekilde karşılanmadığını, özellikle dil-konuşma ve uğraşı terapisi hizmetlerini yeterince alamadıklarını, bunlara ek olarak katılım ve dinlenme haklarını da kullanamadıklarını ve hizmetlerin kaynaştırma ortamında verilmediğini belirtmişlerdir. En kötüsü de, engelli çocuklar kendilerinden sorumlu olan yetişkinler tarafindan istismara en sik uğrayan gruptur (Landsdown, 1998). 
Bakım ve yetiştirilmelerindeki güçlük nedeniyle, engelli çocuklar yetişkinlerin istismarına, diğer çocuklardan daha fazla maruz kalmakta ve bu yüzden daha fazla koruma gerektirmektedir. Engelli erkek çocukların en fazla uğradıkları istismar türleri ihmal ve fiziksel istismar iken, engelli kız çocuklar daha çok cinsel ya da duygusal istismara uğramaktadır (Morris, 1999).

Engelli çocukların özellikle ev ortamı dışında istismara açık oldukları, ayrıca yatılı okula devam etme sıklıklarının, kişisel bakım için başkalarına bağımlı olmalarının, iletişimdeki sınırlılıklarının, kötü niyetli davranışları anlayamamalarının (Paul ve Cawson, 2002), çok sayıda farklı kişiden hizmet almalarının, yetersiz cinsel eğitim almaları ya da hiç almamalarının (Cooke ve Standen, 2002) istismar riskini artırdığı belirtilmektedir. Engelli çocukların istismarının belirlenmesi üzerine bir araştırma yürüten Oosterhorn ve Kendrick (2001), çalışmalarına katılan engellilerle çalışan uzmanların, engelli çocukların iletişim sınırlılıklarından dolayı istismarlarının fark edilmesinin zor olduğunu, bu yüzden engelli çocukların istismara uğrayıp uğramadıklarını bu çocukların doğrudan kendileriyle iletişim kurmaları yoluyla öğrenmelerinin oldukça zor olduğunu söylediklerini belirtmişlerdir. Aynı uzmanlar, bu çocukların istismar edildiklerini, genellikle, fiziksel belirtilerden, davranış değişikliklerinden ya da duygusal değişikliklerinden fark ettiklerini belirtmişlerdir.

Sullivan ve Knutson (2000) engelli çocukların normal gelişim gösteren akranlarından $3.4 \mathrm{kez}$ daha fazla kötü muameleye maruz kaldıklarını belirtmişlerdir. Araştırmacılar ABD'de gerçekleştirdikleri çalışmalarında, elektronik okul kayıtları, polis veri tabanı ve yetiştirme yurdu teftiş heyeti kayıtları üzerinde ayrıntılı inceleme yapmışlardır. Bu inceleme sonucunda, engelli olmayan çocuklarda kötü muameleye maruz kalma oranı \% 9 iken, engelli çocuklar için bu oranın \% 31 olduğu sonucuna ulaşmışlardır. Crosse, Kaye ve Ratnofsky'nin (1992) yine ABD'de gerçekleştirilen çalışmalarında da kötü muameleye uğramış engelli çocukların oranının normal gelişim gösteren akranlarınkinden 1.7 kat daha fazla olduğu bulgusu elde edilmiştir.

Gerçekten de beden, zihin, dil, duygu, sosyal özellikleri ve durumlarındaki ayrıcalıkları nedeniyle genel eğitim hizmetlerinden yararlanamayan ya da kısmen yararlanabilen çocukların haklarının onlara özel hükümlerle yasal güvence altına alınması gerekir (Bıyıklı, 1997; Çağlar, 1997; Harmandar, 1997; Özsoy, 1989). Çocuk Hakları Sözleşmesi’nin 23. maddesinde engelli çocukların hakları ve bu konuda devletin sorumlulukları düzenlenmiştir. Sözleşme'ye göre devlet, zihinsel ya da bedensel engelli çocuklara saygınlıklarını güvence altına alan, öz güvenlerini geliştiren ve toplumsal yaşama etkin bir biçimde katılmalarını kolaylaştıran bir yaşam 
sağlamalıdır. Ayrıca devlet, engelli çocuklara özel bakımdan yararlanma hakkını tanımak, bu durumda olan çocuğa, anne-babasına, bu çocuğun bakımından sorumlu olanlara, eldeki kaynaklarının yeterliliği ölçüsünde içinde bulundukları koşullara uygun yardımların yapılmasını sağlamak ve özendirmekle yükümlüdür. Devlet engelli çocuğa verilecek yardımları, çocuğun eğitim, öğretim, sağlık bakım ve rehabilitasyon hizmetlerini ayrıca işe hazırlanma ve boş zaman değerlendirme firsatlarını mümkün olan en fazla sosyal entegrasyonu sağlayarak ve kültürel, ruhsal gelişimini de gözeterek planlamakla sorumludur. Bu hüküm uyarınca çocuğa sağlanması öngörülen yardımların olanaklar ölçüsünde ücretsiz olması esastır.

Tüm çocukların Sözleşme'nin kendilerine tanıdığı haklar konusunda bilinçlendirilmeleri gerekir. Nitekim Çocuk Hakları Sözleşmesi'nin 42. maddesi de bu tür bir eğitimi öngörmektedir. Ancak Sözleşme'de sadece çocukların değil, yetişkinlerin de Sözleşme hükümleri hakkında uygun ve etkili araçlarla bilgilendirilmesi öngörülmektedir. $\mathrm{Bu}$ hüküm uyarınca, çocuklar ile sürekli iletişim halinde olan, başta anne babalar ve öğretmenler olmak üzere ilgili tüm yetişkinlerin çocuk hakları konusunda eğitilmeleri gerekmektedir.

Çocuk hakları eğitiminin önemini vurgulayan yazarlardan Covell ve Howe (1999) çocuk hakları eğitiminin tüm bireylerde haklara saygı duyma tutum ve davranışının geliştirilmesi için gerekli olduğunu vurgulamışlardır. Yine Covell ve Howe bu eğitimin etkilerini inceledikleri çalışmalarında, bu konuda eğitim alan çocukların almayanlara göre farklı özellikler taşıyan arkadaşlarını daha çabuk kabul ettikleri ve çocukların sahip olmaları gereken hakları daha doğru açıkladıkları sonucuna ulaşmışlardır. Çocuk hakları konusundaki eğitimin öneminin pek çok yazar ve araştırmacı (Cooke ve Standen, 2002; Covell ve Howe, 1999; Crosse ve diğerleri, 1992; Karaman Kepenekci, 2006; Osler ve Starkey, 1998) tarafindan vurgulanmasına karşın bazı çalışmaların sonuçlarından çocuk hakları konusunda bilgili olmaları gereken sosyal hizmet uzmanları (Cooke ve Standen, 2002) ve öğretmenlerin (Casas ve diğ., 2006; Shumba, 2003) bu konuda bir eğitim almadıkları ya da verilen eğitimi yeterli bulmadıkları anlaşılmaktadır. Karaman da (1993) öğretmenlerin, özellikle de sınıf öğretmenlerinin çoğunun çocuğun, istismar ve ihmalden korunması konusunda bilgili olmadıklarını belirtmiştir.

Tüm eğitimler planlanırken de, kuşkusuz, bu eğitimden yararlanacak olanların, diğer deyişle katılımcıların, eğitim verilecek konuya ilişkin tutumlarının bilinmesinde yarar vardır. Çünkü davranışlar önemli ölçüde tutumlardan etkilenmektedir (Bloom, 1995). Diğer bir anlatımla, çocuk haklarına ilişkin olumlu tutum taşıma ile bu alanda verilecek eğitime duyarlılık gösterme arasında doğru bir orantı olduğu söylenebilir. Çocuk 
hakları konusundaki bilgilendirmenin çocuk haklarına yönelik tutumları olumlu yönde etkilediği görülmektedir (Covell ve Howe, 1999). Karaman Kepenekci (2006) insan hakları ya da çocuk haklarına ilişkin ders alan öğrencilerin çocuk haklarına ilişkin tutumlarının, almayan öğrencilerin tutumlarından daha olumlu olduğu sonucuna ulaşmıştır.

Engelli çocukların istismara açık olmalarına ilişkin ortak görüş (Cooke ve Standen, 2002; Morris, 1999; Oosterhorn ve Kendrick, 2000; Paul ve Cawson, 2002) ve bu çocuklar için istismar oranının engelli olmayan çocuklarınkinden yüksek olması gerçeği (Crosse ve diğ., 1992; Sullivan ve Knutson, 2000) engelli çocuklara öğretmenlik yapan ya da onlara hizmet götüren kişilerin çocuk hakları konusunda bilgilendirilmelerinin ve çocuk haklarına yönelik tutumlarının belirlenmesinin önemini gündeme getirmektedir.

Engelli çocuklara ve normal gelişim gösteren çocuklara öğretmenlik yapan ya da onlara hizmet götüren kişilerin çocuk haklarına yönelik tutumlarını belirlemeye yönelik çalışmalardan birinde (Cooke ve Standen, 2002), engelli çocuklarla çalışan sekiz sosyal hizmet uzmanı, engelli çocuklarla çalışan uzmanların bu çocukların istismarını görmezden gelme eğiliminin olduğunu ve bu durumun bilgilendirme ve destek yetersizliğinden kaynaklandığını belirtmişlerdir. Normal gelişim gösteren çocukların öğretmenlerinin çocuk haklarına ilişkin görüşlerinin incelendiği bir diğer çalışmada ise (Casas ve diğerleri, 2006), öğretmenlerin tamamına yakını çocukların kendilerini ifade etme özgürlüklerinin olması gerektiğini, yaklaşık üçte ikisi de çocukların kararlarının dikkate alınması gerektiğini belirtmişlerdir. Aynı araştırmada, öğretmenlerin yarıdan fazlasının ise öğrencilerin on yaşından sonra okul konseyine katılmaları gerektiğini düşündükleri gözlenmiştir. Karaman Kepenekci (2006) tarafindan Türkiye'de yapılan bir çalışmada, öğretmen adaylarının çocuk haklarına ilişsin olumlu tutumlara sahip oldukları sonucuna ulaşılmıştır. Sözü edilen çalışmalara karşın, ilgili alanyazın taraması sonucunda, Türkiye'de özel eğitim öğretmen adaylarının ve öğretmenlerinin çocuk haklarına yönelik tutumlarını ortaya koyan herhangi bir araştırmaya rastlanmamıştır. $\mathrm{Bu}$ çalışma böyle bir gereksinimden yola çıkılarak gerçekleştirilmiştir.

\section{AMAÇ}

$\mathrm{Bu}$ araştırmanın temel amacı, zihin engelliler öğretmen adaylarının çocuk haklarına ilişkin tutumlarını cinsiyete, sınıf düzeyine, insan hakları ya da çocuk haklarına ilişkin bir ders alma durumuna ve yaşa göre incelemektir. Çalışmanın ikincil amacı, zihin engelliler öğretmen adaylarının anılan tutumlarının, sınıf ögretmeni, okul öncesi ögretmeni ve bilgisayar ve öğretim teknolojileri öğretmeni adaylarının tutumlarından farklılaşıp farklılaşmadığını test etmektir. 


\section{YÖNTEM}

Bu bölümde araştırmanın grubu, veri toplama araçları, verilerin analizi konuları tartışılmıştır.

\section{Araștırma Grubu}

Araştırmanın çalışma grubunu Ankara Üniversitesi Eğitim Bilimleri Fakültesi'nin Zihin Engelliler Öğretmenliği (ZEÖ) lisans programı 1. ve 4. sınıflarına devam eden ve araştırmaya katılmaya istekli 85 öğrenci oluşturmuştur. Ayrıca karşıllaştırma yapabilmek amacıyla, aynı Fakülte'nin 1. ve 4. Sınıflarına devam eden Sınıf Öğretmenliği (SÖ), Okul Öncesi Öğretmenliği (OÖÖ) ve Bilgisayar ve Öğretim Teknolojileri Eğitimi (BÖTE) lisans programlarına kayıtlı araştırmaya katılmaya istekli öğrenciler de (202 öğrenci) araştırma grubuna dâhil edilmiştir. Böylece araştırmanın çalışma grubunda toplam 287 öğrenci yer almıştır. Katılımcıların cinsiyete, yaşa, sınıf düzeyine ve insan hakları ya da çocuk haklarına ilişkin bir ders alıp almama durumuna göre dağglımı Tablo 1'de verilmiştir.

Tablo 1. Araştırmaya Katılan Öğrencilerin Kişisel Bilgileri

\begin{tabular}{cccccccccc}
\hline \multirow{2}{*}{ Kişisel Bilgiler } & \multicolumn{8}{c}{ Lisans Programları } \\
\cline { 3 - 10 } & & \multicolumn{2}{c}{ ZEÖ } & \multicolumn{2}{c}{ SÖ } & OÖÖ & \multicolumn{2}{c}{ BÖTE } \\
\cline { 3 - 10 } Cinsiyet & K1Z & 57 & 67.1 & 53 & 65.4 & 74 & 96.1 & 22 & 50 \\
& Erkek & 28 & 32.9 & 28 & 34.6 & 3 & 3.9 & 22 & 50 \\
& Toplam & 85 & 100.0 & 81 & 100.0 & 77 & 100.0 & 44 & 100.0 \\
& 17 & - & - & 1 & 1.2 & - & - & 1 & 2.3 \\
& 18 & 1 & 1.2 & 8 & 9.9 & 5 & 6.5 & 2 & 4.5 \\
& 19 & 15 & 17.6 & 20 & 24.7 & 16 & 20.8 & 4 & 9.1 \\
& 20 & 9 & 10.6 & 7 & 8.6 & 14 & 18.2 & 10 & 22.7 \\
& 21 & 16 & 18.8 & 13 & 16.0 & 6 & 7.8 & 4 & 9.1 \\
Yaş & 22 & 8 & 9.4 & 9 & 11.1 & 14 & 18.2 & 10 & 22.7 \\
& 23 & 12 & 14.1 & 18 & 22.2 & 12 & 15.6 & 6 & 13.6 \\
& 24 & 9 & 10.6 & 1 & 1.2 & 7 & 9.1 & 3 & 6.8 \\
& 25 & 9 & 10.6 & 3 & 3.7 & 3 & 3.9 & 4 & 9.1 \\
& $26+$ & 6 & 7.1 & 1 & 1.2 & - & - & - & - \\
Sinıf & Toplam & 85 & 100.0 & 81 & 100.0 & 77 & 100.0 & 44 & 100.0 \\
düzeyi & 1 & 37 & 43.5 & 41 & 50.6 & 36 & 46.8 & 23 & 52.3 \\
& 4 & 48 & 56.5 & 40 & 49.4 & 41 & 53.2 & 21 & 47.7 \\
& Toplam & 85 & 100.0 & 81 & 100.0 & 77 & 100.0 & 44 & 100.0 \\
Ders & Evet & - & - & 38 & 46.9 & 18 & 23.4 & - & - \\
alma & Hayır & 85 & 100.0 & 43 & 53.1 & 59 & 76.6 & 44 & 100.0 \\
& Toplam & 85 & 100.0 & 81 & 100.0 & 77 & 100.0 & 44 & 100.0 \\
\hline
\end{tabular}


Araştırmaya katılan ZEÖ Programı öğrencilerinin çoğunluğunun (\% $67.1) \mathrm{klz}$ olduğu, en fazla öğrencinin 21 (\%18.8), 19 (\%17.6) ve 23 (\%14.1) yaş gruplarında bulunduğu, \%43.5'inin 1 . sınıfta, \%56.5'inin ise 4. sınıfta okuduğu ve hiçbirinin insan hakları ya da çocuk hakları ile ilgili bir ders almadığı görülmüştür.

\section{Veri Toplama Araçları}

Araştırmada veri toplamak amacıyla "Kişisel Bilgi Formu" ile "Çocuk Haklarına İlişkin Tutum Ölçeği” kullanılmıştır.

Araştırmada öncelikle araştırmacılar tarafından hazırlanan katılımcıların cinsiyet, yaş, sınıf düzeyi, insan hakları ya da çocuk haklarına ilişkin bir ders alıp almadıklarına ilişkin soruların bulunduğu bir kişisel bilgi formu kullanılmıştır. Üniversite öğrencilerinin çocuk haklarına ilişkin tutumlarını belirlemek amaciyla daha önce Karaman Kepenekci (2006) tarafindan geliştirilen Çocuk Haklarına İlişkin Tutum Ölçeği (ÇHTÖ) kullanılmıştır.

Ölçek 5'li likert formunda hazırlanmıştır. Ölçekte çocukların yaşamsal, gelişimsel, korunma ve katılım haklarına ilişkin 22 madde bulunmaktadır. $\mathrm{Bu}$ ifadeler için "Tamamen Katılıyorum", "Katılıyorum", "Kararsızım", "Katılmıorum" ve "Tamamen Katılmıorum" tepki seçenekleri bulunmaktadır. İfadelere verilen tepkiler aynı sırayla 1, 2, 3, 4, ve 5 olarak puanlanmakta olup, ölçekten alınan puanın yüksek olması olumsuz tutumu göstermektedir. Ölçekteki ifadelerin 19'u olumlu, 3'ü olumsuzdur. Olumsuz ifadelere (2., 14. ve 15. maddeler) verilen tepkiler ters puanlanmaktadır. Ölçekten alınacak en düşük puan 22 ve en yüksek puan ise 110 'dur.

Karaman Kepenekci (2006) ölçeğin geçerliğine ve güvenirliğine ilişkin yaptığı çalışma sonucunda, ölçeğin tek faktörlü olduğunu, ölçekteki maddelerin madde toplam korelasyon katsayılarının .32 ile .61 arasinda değiştiğini, Cronbach Alpha iç tutarlılık katsayısının .85, yarı test güvenirlik katsayısının ise .77 olarak belirlendiğini ifade etmiştir.

\section{Verilerin Analizi}

ZEÖ lisans programı öğrencilerinin ÇHTÖ’nden elde ettikleri puanların cinsiyete ve sınıf düzeyine göre farklılaşıp farklılaşmadığını belirlemek amacıyla grubun tutum puanlarına ilişkin çarpıklık ve sivrilik katsayılarının cinsiyet ve sınıf düzeyi değişkenlerinin her bir düzeyi için 1'den büyük olması ve Kolmogorov-Smirnov değerlerinin anlamlı çıkması nedeniyle İlişkisiz Ölçümler İçin Kruskal Wallis H-Testi kullanılmıştır. ZEÖ lisans programı öğrencilerinin ÇHTÖ'nden elde ettikleri puan ile yaş ilişkisine Spearman Brown sıra farkları korelasyon katsayısı kullanılarak bakılmıştır. 
ZEÖ, SÖ, OÖÖ ve BÖTE lisans programı öğrencilerinin çocuk haklarına yönelik tutum puanlarının farklılaşıp farklılaşmadığı, tutum puanlarına ilişkin çarpıklık ve sivrilik katsayılarının bağımsız değişkenin her bir düzeyinde 1'den büyük olmas1, Kolmogorov-Smirnov değerlerinin anlamlı çıkması ve ayrıca bağımlı değişkene ilişkin varyansların eşit olmaması nedeniyle İlişkisiz Ölçümler İçin Kruskal Wallis H-Testi kullanılarak incelenmiştir. Farkın kaynağını belirlemek amacıyla da İlişkisiz Ölçümler İçin Mann Whitney U Testi kullanılmıştır. Cinsiyet, sınıf düzeyi ve insan hakları ya da çocuk hakları ile ilgili bir ders alma değişkenlerinin araştırmaya katılan tüm öğrencilerin tutum puanlarına etkisini incelemek amacıyla İlişkisiz Ölçümler için Kruskal Wallis H Testi kullanılmıştır. İnsan hakları ya da çocuk hakları ile ilgili bir ders almayanların tutum puanlarının lisans programına, cinsiyete ve sınıf düzeyine göre farklılaşıp farklılaşmadığını belirlemek amacıyla yine Kruskal Wallis $\mathrm{H}$ Testi kullanılmıştır. Araştırmaya katılan tüm öğrencilerin tutum puanları ile yaş ilişkisini belirlemek için ise Spearman Brown sıra farkları korelasyon katsayısı kullanılmıştır. Anlamlılık düzeyi olarak .05 düzeyi benimsenmiştir.

\section{SINIRLILIKLAR}

Bu araştırma 2006-2007 Eğitim-Öğretim Yılında Ankara Üniversitesi Eğitim Bilimleri Fakültesi'nin ZEÖ lisans programı öğrencileri ile SÖ, OÖÖ ve BÖTE lisans programı 1. ve 4. sınıf öğrencilerinden araştırmaya katılmaya gönüllü olanlardan elde edilen verilerle sınırlıdır.

\section{BULGULAR}

ZEÖ lisans programı öğrencilerinin ÇHTÖ'ndeki her maddeye ilişkin katılım düzeyleri ortaya konulmaya çalışılmışıı. Tablo 2'de ZEÖ lisans programı ögrencilerinin ÇHTÖ'ndeki her maddeye ilişkin katılımları frekans ve yüzde olarak sunulmuştur. 
Tablo 2. ZEÖ Lisans Öğrencilerinin ÇHTÖ'nin Maddelerine Illişkin Katıllımlarının Frekans (F) ve Yüzde (\%) Dă̆llumları

\begin{tabular}{|c|c|c|c|c|c|c|c|}
\hline $\begin{array}{l}\text { Madde } \\
\text { No }\end{array}$ & Maddeler & 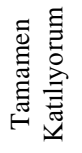 & 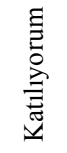 & 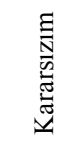 & 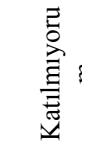 & 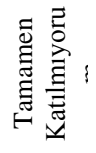 & $\frac{\Xi}{\frac{\Xi}{2}}$ \\
\hline & & $\begin{array}{l}\text { F- } \\
\%\end{array}$ & $\begin{array}{l}\text { F- } \\
\%\end{array}$ & $\begin{array}{l}\text { F- } \\
\%\end{array}$ & $\begin{array}{l}\text { F- } \\
\%\end{array}$ & $\begin{array}{l}\text { F- } \\
\%\end{array}$ & $\begin{array}{l}\text { F- } \\
\%\end{array}$ \\
\hline 1 & $\begin{array}{l}18 \text { yaşın altındaki herkesin çocuk } \\
\text { olmaktan kaynaklanan özel haklara } \\
\text { sahip olduğuna inanıorum. }\end{array}$ & $\begin{array}{c}42 \\
49.4\end{array}$ & $\begin{array}{c}35 \\
41.2\end{array}$ & $\begin{array}{c}2 \\
2.4\end{array}$ & $\begin{array}{c}4 \\
4.7\end{array}$ & $\begin{array}{c}2 \\
2.4\end{array}$ & $\begin{array}{c}85 \\
100.0\end{array}$ \\
\hline $2 *$ & $\begin{array}{l}\text { Çocuk hakları konusunda özel bir } \\
\text { uluslar arası sözleşme hazırlanmasına } \\
\text { gerek yoktur. }\end{array}$ & $\begin{array}{c}4 \\
4.7\end{array}$ & $\begin{array}{c}5 \\
5.9\end{array}$ & $\begin{array}{c}8 \\
9.4\end{array}$ & $\begin{array}{c}26 \\
30.6\end{array}$ & $\begin{array}{c}42 \\
49.4\end{array}$ & $\begin{array}{c}85 \\
100.0\end{array}$ \\
\hline 3 & $\begin{array}{l}\text { Çocuk hakları devlet tarafından koruma } \\
\text { altına almalıdır. }\end{array}$ & $\begin{array}{c}60 \\
70.6 \\
\end{array}$ & $\begin{array}{c}22 \\
25.9 \\
\end{array}$ & $\begin{array}{c}2 \\
2.4 \\
\end{array}$ & - & $\begin{array}{c}1 \\
1.2 \\
\end{array}$ & $\begin{array}{c}85 \\
100.0 \\
\end{array}$ \\
\hline 4 & $\begin{array}{l}\text { Devletler, çocuklarını daha iyi } \\
\text { yetiştirmeleri için ailelere yardımcı } \\
\text { olmalıdır. }\end{array}$ & $\begin{array}{c}59 \\
69.4\end{array}$ & $\begin{array}{c}22 \\
25.9\end{array}$ & - & $\begin{array}{c}2 \\
2.4\end{array}$ & $\begin{array}{c}2 \\
2.4\end{array}$ & $\begin{array}{c}85 \\
100.0\end{array}$ \\
\hline 5 & $\begin{array}{l}\text { Çocuğun en temel hakkının "yaşama } \\
\text { hakkı" olduğuna inanıyorum. }\end{array}$ & $\begin{array}{c}63 \\
74.1 \\
\end{array}$ & $\begin{array}{c}18 \\
21.2 \\
\end{array}$ & $\begin{array}{c}2 \\
2.4 \\
\end{array}$ & $\begin{array}{c}1 \\
1.2 \\
\end{array}$ & $\begin{array}{c}1 \\
1.2 \\
\end{array}$ & $\begin{array}{c}85 \\
100.0 \\
\end{array}$ \\
\hline 6 & $\begin{array}{l}\text { Annesinden, babasından ya da her } \\
\text { ikisinden de ayrı olan çocukların anne- } \\
\text { babasını görme hakkı vardır. }\end{array}$ & $\begin{array}{c}67 \\
78.8\end{array}$ & $\begin{array}{c}14 \\
16.5\end{array}$ & $\begin{array}{c}1 \\
1.2\end{array}$ & $\begin{array}{c}2 \\
2.4\end{array}$ & $\begin{array}{c}1 \\
1.2\end{array}$ & $\begin{array}{c}85 \\
100.0\end{array}$ \\
\hline 7 & $\begin{array}{lccr}\text { Devletler } & \text { farklı ülkelerde } & \text { yaşayan } \\
\text { parçalanmış } & \text { ailelere bir } & \text { arada } \\
\text { yaşamaları için gerekli } & \text { yardımı } \\
\text { sağlamalıdır. } & & \\
\end{array}$ & $\begin{array}{c}55 \\
64.7\end{array}$ & $\begin{array}{c}19 \\
22.4\end{array}$ & $\begin{array}{c}6 \\
7.1\end{array}$ & $\begin{array}{c}3 \\
3.5\end{array}$ & $\begin{array}{c}1 \\
1.2\end{array}$ & $\begin{array}{c}84 \\
98.8 * *\end{array}$ \\
\hline 8 & $\begin{array}{l}\text { Çocukların düşüncelerini yazarak ya da } \\
\text { çizerek anlatma hakları olduğunu } \\
\text { düşünüyorum. }\end{array}$ & $\begin{array}{c}55 \\
64.7\end{array}$ & $\begin{array}{c}25 \\
29.4\end{array}$ & $\begin{array}{c}4 \\
4.7\end{array}$ & - & $\begin{array}{c}1 \\
1.2\end{array}$ & $\begin{array}{c}85 \\
100\end{array}$ \\
\hline 9 & $\begin{array}{l}\text { Çocukların özel yaşamı vardır bu } \\
\text { yüzden de özel yaşamlarının gizliliğine } \\
\text { saygı gösterilmelidir. }\end{array}$ & $\begin{array}{c}49 \\
57.6\end{array}$ & $\begin{array}{c}26 \\
30.6\end{array}$ & $\begin{array}{c}5 \\
5.9\end{array}$ & $\begin{array}{c}3 \\
3.5\end{array}$ & $\begin{array}{c}1 \\
1.2\end{array}$ & $\begin{array}{c}84 \\
98.8 * *\end{array}$ \\
\hline 10 & $\begin{array}{l}\text { Devlet çocuğu her türlü kötü } \\
\text { muameleden korumalıdır. }\end{array}$ & $\begin{array}{c}66 \\
77.6 \\
\end{array}$ & $\begin{array}{c}15 \\
17.6 \\
\end{array}$ & - & $\begin{array}{c}4 \\
4.7 \\
\end{array}$ & - & $\begin{array}{c}85 \\
100.0 \\
\end{array}$ \\
\hline 11 & $\begin{array}{l}\text { Evsiz çocukların devlet tarafindan } \\
\text { korunması ve yetiştirilmesi gerektiğini } \\
\text { düşünüyorum. }\end{array}$ & $\begin{array}{c}65 \\
76.5\end{array}$ & $\begin{array}{c}16 \\
18.8\end{array}$ & $\begin{array}{c}1 \\
1.2\end{array}$ & $\begin{array}{l}- \\
-\end{array}$ & $\begin{array}{c}3 \\
3.5\end{array}$ & $\begin{array}{c}85 \\
100.0\end{array}$ \\
\hline 12 & $\begin{array}{l}\text { Anne-babasıyla yaşama şansı olmayan } \\
\text { çocukların, uygun ailelere evlatlık } \\
\text { olarak verilme veya koruyucu aile } \\
\text { yanına yerleştirilme hakkı vardır. }\end{array}$ & $\begin{array}{c}53 \\
62.4\end{array}$ & $\begin{array}{c}23 \\
27.1\end{array}$ & $\begin{array}{c}5 \\
5.9\end{array}$ & $\begin{array}{c}2 \\
2.4\end{array}$ & $\begin{array}{c}2 \\
2.4\end{array}$ & $\begin{array}{c}85 \\
100.0\end{array}$ \\
\hline 13 & $\begin{array}{l}\text { Devlet engelli çocukları korumak, } \\
\text { eğitmek ve istihdam etmek için gerekli } \\
\text { önlemleri almalıdır. }\end{array}$ & $\begin{array}{c}70 \\
82.4\end{array}$ & $\begin{array}{c}12 \\
14.1\end{array}$ & $\begin{array}{c}1 \\
1.2\end{array}$ & $\begin{array}{c}1 \\
1.2\end{array}$ & $\begin{array}{c}1 \\
1.2\end{array}$ & $\begin{array}{c}85 \\
100.0\end{array}$ \\
\hline $14 *$ & $\begin{array}{l}\text { Çocukların sağlıkları ile ilgili } \\
\text { sorumluluk sadece ailelerde olmalıdır; } \\
\text { devletler çocukların sağlık sorunlarına } \\
\text { karışmamalıdır. }\end{array}$ & $\begin{array}{c}5 \\
5.9\end{array}$ & $\begin{array}{c}2 \\
2.4\end{array}$ & $\begin{array}{c}3 \\
3.5\end{array}$ & $\begin{array}{c}13 \\
15.3\end{array}$ & $\begin{array}{c}62 \\
72.9\end{array}$ & $\begin{array}{c}85 \\
100.0\end{array}$ \\
\hline $15 *$ & $\begin{array}{l}\text { Sadece yetişkinlerin sosyal güvenlik } \\
\text { hakkı olmalıdır; çocuklara sosyal } \\
\text { güvenlik hakkı tanımaya gerek yoktur. }\end{array}$ & $\begin{array}{c}4 \\
4.7\end{array}$ & $\begin{array}{c}1 \\
1.2\end{array}$ & $\begin{array}{c}1 \\
1.2\end{array}$ & $\begin{array}{c}20 \\
23.5\end{array}$ & $\begin{array}{c}59 \\
69.4\end{array}$ & $\begin{array}{c}85 \\
100.0\end{array}$ \\
\hline
\end{tabular}




\begin{tabular}{|c|c|c|c|c|c|c|c|}
\hline 16 & $\begin{array}{l}\text { Devletlerin ailelere çocuklarına daha iyi } \\
\text { yaşam standartları } \quad \text { sağlamaları } \\
\text { konusunda yardım etmeleri gerektiğine } \\
\text { inanıyorum. }\end{array}$ & $\begin{array}{c}66 \\
77.6\end{array}$ & $\begin{array}{c}16 \\
18.8\end{array}$ & $\begin{array}{c}1 \\
1.2\end{array}$ & $\begin{array}{l}- \\
-\end{array}$ & $\begin{array}{c}2 \\
2.4\end{array}$ & $\begin{array}{c}85 \\
100.0\end{array}$ \\
\hline 17 & $\begin{array}{l}\text { Oyun oynamanın ve farklı etkinliklere } \\
\text { katılmanın çocukların hakkı olduğunu } \\
\text { düşünüyorum. }\end{array}$ & $\begin{array}{c}59 \\
69.4\end{array}$ & $\begin{array}{c}24 \\
28.2\end{array}$ & - & $\begin{array}{c}1 \\
1.2\end{array}$ & $\begin{array}{c}1 \\
1.2\end{array}$ & $\begin{array}{c}85 \\
100.0\end{array}$ \\
\hline 18 & $\begin{array}{l}\text { Çocukların madde kullanımına karşı } \\
\text { korunmaları gerektiğine inanıyorum. }\end{array}$ & $\begin{array}{c}66 \\
77.6\end{array}$ & $\begin{array}{c}17 \\
20.0\end{array}$ & $\begin{array}{c}1 \\
1.2\end{array}$ & - & $\begin{array}{c}1 \\
1.2\end{array}$ & $\begin{array}{c}85 \\
100.0\end{array}$ \\
\hline 19 & $\begin{array}{l}\text { Çocukların istismar ve ihmalin tüm } \\
\text { türlerine karşı korunması gerekir. }\end{array}$ & $\begin{array}{c}66 \\
77.6 \\
\end{array}$ & $\begin{array}{c}16 \\
18.8 \\
\end{array}$ & $\begin{array}{c}1 \\
1.2 \\
\end{array}$ & $\begin{array}{c}1 \\
1.2 \\
\end{array}$ & $\begin{array}{c}1 \\
1.2 \\
\end{array}$ & $\begin{array}{c}85 \\
100.0 \\
\end{array}$ \\
\hline 20 & $\begin{array}{l}\text { Çocukların savaşlardan korunmaları } \\
\text { gerektiğine inanıyorum. }\end{array}$ & $\begin{array}{c}68 \\
80.0\end{array}$ & $\begin{array}{c}15 \\
17.6 \\
\end{array}$ & $\begin{array}{c}1 \\
1.2 \\
\end{array}$ & - & $\begin{array}{c}1 \\
1.2 \\
\end{array}$ & $\begin{array}{c}85 \\
100.0 \\
\end{array}$ \\
\hline 21 & $\begin{array}{l}\text { Devletler istismara ve ihmale uğramış } \\
\text { çocukların tedavi ve terapileri için her } \\
\text { türlü önlemi almak zorundadır. }\end{array}$ & $\begin{array}{c}63 \\
74.1\end{array}$ & $\begin{array}{c}18 \\
21.2\end{array}$ & $\begin{array}{c}1 \\
1.2\end{array}$ & - & $\begin{array}{c}3 \\
3.5\end{array}$ & $\begin{array}{c}85 \\
100.0\end{array}$ \\
\hline 22 & $\begin{array}{l}\text { Suç işlemiş çocuklara, sağlıklı ve sosyal } \\
\text { yurttaşlar olabilmeleri için yardım } \\
\text { edilmesi gerektiğine inanıyorum. }\end{array}$ & $\begin{array}{c}61 \\
71.8\end{array}$ & $\begin{array}{c}21 \\
24.7\end{array}$ & $\begin{array}{c}2 \\
2.4\end{array}$ & - & $\begin{array}{c}1 \\
1.2\end{array}$ & $\begin{array}{c}85 \\
100.0\end{array}$ \\
\hline
\end{tabular}

* Ters maddeler

** Toplam oranların \%100 olmamasının nedeni, bu ifadelere yanıt vermemeden kaynaklanan kayıp verilerin olmasıdır.

Tablo 2 genel olarak incelendiğinde, ZEÖ lisans programı öğrencilerinin ÇHTÖ’ndeki maddelere verdikleri tepkilerin dağılımlarının, en çok tamamen katılıyorum ve katılıyorum seçeneklerinde yığgldığ maddelerde (2., 14., ve 15.) ise hiç katılmıyorum ve katılmiyorum seçeneklerinde toplandığı görülmektedir.

ZEÖ lisans programı öğrencilerinin ÇHTÖ’nden elde ettikleri puanların cinsiyete ve sınıf düzeyine göre farklılaşıp farklılaşmadı̆̆ını belirlemek amacıyla kullanılan İlişkisiz Ölçümler İçin Kruskal Wallis H-Testi sonuçları, ZÖE programı lisans öğrencilerinin çocuk haklarına yönelik tutumlarının cinsiyete $\left[\chi^{2}(1)=.163, p=.687\right]$ ve sinıf düzeyine $\left[\chi^{2}(1)=2.09, p=.148\right]$ göre farklılaşmadığını göstermiştir. ZEÖ lisans programı öğrencilerinin çocuk haklarına yönelik tutum puanlarının yaş ile ilişkisinin olup olmadığını belirlemek amaciyla kullanılan Spearman Brown sira farkları korelasyon katsayısı sonuçları grubun çocuk haklarına yönelik tutumları ile yaşları arasında da bir ilişkinin olmadığını göstermiştir $(\mathrm{r}=.05, \mathrm{p}=.654)$. ZEÖ lisans programı öğrencileri insan hakları ya da çocuk hakları ile ilgili bir ders almadıkları için bu değişkenin grubun çocuk haklarına yönelik tutumları üzerindeki etkisi incelenememiştir.

ZEÖ programı öğrencilerinin çocuk haklarına yönelik tutum puanlarının, SÖ, OÖÖ ve BÖTE programı öğrencilerinin bu alandaki tutum puanlarından farklılaşıp farklılaşmadığını belirlemek amacıyla kullanılan İlişkisiz Ölçümler için Kruskal Wallis H Testi sonuçları (Tablo 3), çocuk haklarına yönelik tutum puanlarının lisans programlarına göre farklılaştığını göstermektedir. 
Tablo 3. ZEÖ, SÖ, OÖÖ ve BÖTE Lisans Öğrencilerinin Çocuk Haklarina Yönelik Tutum Puanlarının Karşılaş̧ırılmasına Ait Kruskal Wallis H-Testi Sonuçları

\begin{tabular}{lcccccc}
\hline Lisans Programları & $\overline{\mathrm{x}}$ & $\mathrm{n}$ & $\begin{array}{c}\text { Sıra } \\
\text { Ortalamaları }\end{array}$ & $\mathrm{sd}$ & $\chi^{2}$ & $\mathrm{p}$ \\
\hline ZEÖ Programı & 31.16 & 85 & 154.31 & 3 & 14.12 & .003 \\
SÖ Programı & 27.19 & 81 & 125.14 & & & \\
OÖÖ Programı & 27.60 & 77 & 133.22 & & & \\
BÖTE Programı & 31.39 & 44 & 177.66 & & & \\
\hline
\end{tabular}

Farklılığın hangi gruplar arasında olduğunu belirlemek amaciyla kullanılan İlişkisiz Ölçümler İçin Mann Whitney U Testi sonuçlarına (Tablo 4) bakıldığında, ZEÖ programı öğrencilerinin puanları, BÖTE ve OÖÖ programı öğrencilerinin puanlarından farklılaşmazken, SÖ programı öğrencilerinin puanları ile farklılaştığı görülmüştür. Tablo 4'teki sıra ortalamalarına bakıldığında, ZEÖ öğrencilerinin çocuk haklarına ilişkin tutumlarının SÖ öğrencilerinin tutumlarından daha olumsuz olduğu söylenebilir.

Tablo 4. ZEÖ Lisans Öğrencilerinin Çocuk Haklarına Yönelik Tutum Puanlarının Diğer Program Öğrencilerinin Puanlarıyla Karşılaştırılmasına Ait İlişkisiz Ölçümler İçin Mann Whitney U-Testi Sonuçları

\begin{tabular}{lccccc}
\hline Programlar & $\mathrm{n}$ & $\begin{array}{c}\text { Sira } \\
\text { Ortalamaları }\end{array}$ & Sira Toplamı & $\mathrm{U}$ & $\mathrm{p}$ \\
\hline ZEÖ Program1 & 85 & 91.24 & 7755.50 & 2784.50 & .033 \\
SÖ Programı & 81 & 75.38 & 6105.50 & & \\
\hline ZEÖ Programı & 85 & 87.05 & 7399.50 & 2800.50 & .112 \\
OÖÖ Programı & 77 & 75.37 & 5803.50 & & \\
\hline ZEÖ Programı & 85 & 62.02 & 5271.50 & 1616.50 & .207 \\
BÖTE Programı & 44 & 70.76 & 3113.50 & & \\
\hline
\end{tabular}

Cinsiyet, sınıf düzeyi ve insan hakları ya da çocuk haklarına ilişkin ders alma değişkenlerinin araştırmaya katılan tüm öğrencilerin (ZEÖ, SÖ, OÖÖ ve BÖTE) çocuk haklarına ilişkin tutumlarını farklılaştırıp farklılaştırmadığını belirlemek amacıyla kullanılan İlişkisiz Ölçümler İçin Kruskal Wallis H-Testi sonucu, cinsiyetin tutumlar üzerinde anlamlı bir etkiye sahip olmadığını göstermiştir $\left[\chi^{2}(1)=2.08, \mathrm{p}=.149\right]$.

Sınıf düzeyi değişkeninin araştırmaya katılan tüm öğrencilerin çocuk haklarına ilişkin tutumları üzerinde etkili olup olmadığını belirlemek amacıyla kullanılan İlişkisiz Ölçümler İçin Kruskal Wallis H-Testi sonucu, sınıf düzeyinin çocuk haklarına ilişkin tutumlar üzerinde anlamlı bir etkiye 
sahip olduğunu göstermiştir $\left[\chi^{2}(1)=11.83, p=.001\right]$. Sira ortalamaları incelendiğinde, 1. sınıf öğrencilerinin sıra ortalamalarının (161.57) 4. sınıf öğrencilerinin sıra ortalamalarından (127.95) daha yüksek olduğu görülmüsstür. Bu durum 1. sınıf öğrencilerinin 4. sınıf öğrencilerinden daha olumsuz tutumlara sahip olduğunu göstermektedir.

İnsan hakları ya da çocuk haklarına ilişkin ders alma değişkeninin araştırmaya katılan tüm öğrencilerin çocuk haklarına ilişkin tutumları üzerindeki etkisini ortaya koymak için yapılan İlişkisiz Ölçümler İçin Kruskal Wallis H-Testi sonuçları, ilgili dersleri almanın tutumlar üzerinde anlamlı bir etkiye sahip olduğunu göstermiştir $\left[\chi^{2}(1)=35.94, p=.000\right]$. Ders alanların sıra ortalamasının 84.54 , almayanlarınkinin ise 158.41 olduğu göz önüne alındığında, ilgili dersleri almanın tutumları olumlu bir hale getirdiği görülmektedir.

İnsan hakları ya da çocuk haklarına ilişkin ders almanın çocuk haklarına yönelik tutumları olumlu olarak etkilediğine ilişkin elde edilen bulgunun, insan hakları ya da çocuk haklarına ilişkin bir ders almamış olanların çocuk haklarına yönelik tutum puanlarının programlara göre incelenmesini gerektirdiği düşünülmüştür. Bu amaçla, insan hakları ya da çocuk haklarına ilişkin bir ders almamış olanların çocuk haklarına yönelik tutum puanlarının, lisans programlarına göre farklılaşıp farklılaşmadığını ortaya koymak amacıyla İlişkisiz Ölçümler İçin Kruskal Wallis H-Testi kullanılmıştır. Testin sonuçları, insan hakları ya da çocuk haklarına ilişkin bir ders almamış olan lisans öğrencilerinin çocuk haklarına yönelik tutum puanlarının lisans programına göre farklılaşmadığını göstermiştir $\left[\chi^{2}(3)=3.37, p=.339\right]$.

İnsan hakları ya da çocuk haklarına ilişkin bir ders almamış olanların çocuk haklarına yönelik tutum puanlarının, cinsiyete göre farklılaşıp farklılaşmadığını ortaya koymak amacıyla kullanılan İlişkisiz Ölçümler İçin Kruskal Wallis H-Testi sonuçları, insan hakları ya da çocuk haklarına ilişkin bir ders almamış olan lisans öğrencilerin çocuk haklarına yönelik tutum puanlarının cinsiyete göre farklılaştığını göstermiştir $\left[\chi^{2}(1)=4.55, \mathrm{p}=.033\right]$. Kizların sira ortalamalarının 110.21, erkeklerin ise 131.12 olduğu dikkate alındığında, insan hakları ya da çocuk hakları ile ilgili ders almamış kız öğrencilerin erkek öğrencilere göre çocuk haklarına ilişkin daha olumlu tutumlara sahip oldukları söylenebilir. Araştırmada, yukarıda da belirtildiği gibi, tüm öğrenciler için cinsiyetin çocuk haklarına ilişkin tutumları etkilemediği ortaya çıkarken, insan hakları ya da çocuk haklarına ilişkin bir ders almamış öğrenci grubu için cinsiyetin tutumları etkilediği ve kız öğrencilerin tutumlarının erkek öğrencilerin tutumlarından daha olumlu olduğu görülmüştür. Bunun yanında, insan hakları ya da çocuk haklarına 
ilişkin bir ders almış olanların çocuk haklarına yönelik tutum puanlarının, cinsiyete göre farklılaşıp farklılaşmadığını ortaya koymak amaciyla kullanılan İlişkisiz Ölçümler İçin Kruskal Wallis H-Testi sonuçları, insan hakları ya da çocuk haklarına ilişkin bir ders almış olan lisans öğrencilerin çocuk haklarına yönelik tutum puanlarının cinsiyete göre farklılaşmadığını göstermiş̧tir $\left[\chi^{2}(1)=.09, \mathrm{p}=.771\right]$.

Araştırmaya katılan tüm öğrencilerin (ZEÖ, SÖ, OÖÖ ve BÖTE) çocuk haklarına yönelik tutum puanlarının yaş ile ilişkisinin olup olmadığını belirlemek amaciyla kullanılan Spearman Brown sira farkları korelasyon katsayısı sonuçları öğrencilerin çocuk haklarına yönelik tutumları ile yaşları arasında olumsuz, düşük ve anlamlı bir ilişkinin olduğunu göstermiştir ( $\mathrm{r}=$ $.12, \mathrm{p}=.042)$. Bu durumda, öğrencilerin yaşları artıkça tutum puanlarının düştüğü, bir başka anlatımla tutumlarının daha olumlu bir duruma geldiği söylenebilir.

\section{TARTIŞMA}

$\mathrm{Bu}$ çalışmada, zihin engelliler öğretmen adaylarına sunulmasında yarar görülen "çocuk hakları eğitimi” çalışmalarının düzenlenmesine veri sağlaması amacıyla; zihin engelliler öğretmen adaylarının çocuk haklarına yönelik tutumları ortaya konulmaya çalışılmıştır. Bu doğrultuda Karaman Kepenekci tarafından geliştirilen (2006) "Çocuk Haklarına İlişkin Tutum Ölçeği” (ÇHTÖ) zihin engelliler öğretmen adaylarına uygulanmıştır. Ölçeğin uygulanması sonunda, ZEÖ Programı öğrencilerinin önemli bir çoğunluğu ölçeğin maddelerinde tamamen katılıyorum ya da katılıyorum seçeneklerini işaretlemiş̧lerdir. Bu durumda bu öğrencilerin çocuk haklarına ilişkin genelde olumlu bir tutuma sahip oldukları söylenebilir.

$\mathrm{Bu}$ çalışmada, ZEÖ programı öğrencilerinin çocuk haklarına yönelik tutumlarını daha açık bir şekilde ortaya koyabilmek üzere, BÖTE, OÖÖ ve SÖ programlarına kayıtlı öğretmen adaylarına da aynı ölçek uygulanmış ve uygulama sonucu elde edilen tutum puanları ile ZEÖ programı öğrencilerinin puanları karşılaştırılmıştır. Sonuç olarak, ZEÖ programı öğrencileri ile BÖTE ve OÖÖ programı öğrencilerinin tutum puanları farklılaşmamış, bununla birlikte, ZEÖ Programı öğrencilerinin SÖ öğrencilerinden daha olumsuz tutumlara sahip oldukları belirlenmiştir.

Dikkati çekici bir diğer nokta, grupların çocuk hakları ya da insan haklarına ilişkin ders alma oranlarındaki farklılıktır. ZEÖ ve BÖTE programı öğrencilerinden çocuk hakları ya da insan haklarına ilişkin ders alan olmamıştır. SÖ öğrencilerinin ise neredeyse yarıya yakını, OÖÖ öğrencilerinin ise yaklaşık dörtte biri çocuk hakları ya da insan haklarına ilişkin ders almıştır. Araştırmanın bulguları dikkate alındığında, insan 
hakları ya da çocuk haklarına ilişkin ders alan katılımcıların çocuk haklarına ilişkin tutumlarının, ders almayan katılımcıların tutumlarına göre daha olumlu olduğu görülmüştür. Bu bulgunun yanı sıra insan hakları ya da çocuk haklarına ilişkin bir ders almamış olanların çocuk haklarına yönelik tutum puanlarının programlara göre farklılaşmadığı da gözlenmiştir. Tüm bu bulgular dikkate alındığında, grupların (ZEÖ, SÖ, OÖÖ, BÖTE) tutum puanları arasındaki farkın insan hakları ya da çocuk haklarına ilişkin ders alma ile ilişkili olduğu, bu konuda ders almanın tutumları olumlu olarak etkilediği söylenebilir.

İnsan hakları ya da çocuk haklarına ilişkin ders almanın çocuk haklarına yönelik tutumları olumlu olarak etkilediğine ilişkin bulgular, Covell ve Howe'un (1999) çocuk hakları konusundaki bilgilendirmenin çocuk haklarına yönelik tutumları olumlu yönde etkilediğine ilişkin bulgusuyla ve Karaman Kepenekci'nin (2006) insan hakları ya da çocuk haklarına ilişkin ders alan öğrencilerin çocuk haklarına ilişkin tutumlarının almayan öğrencilerin tutumlarından daha olumlu olduğu bulgusuyla da desteklenmektedir.

Bilindiği üzere, Çocuk Hakları Sözleşmesi'nde tüm çocukların hakları yanında, özel gereksinimli çocuklar gibi özel durumda bulunan çocukların hakları da hükme bağlanmıştır. Ayrıca Sözleşme'nin 42. maddesinde, bu Sözleşme'de yer alan hükümlerin herkes tarafindan öğrenilmesi öngörülmüştür. $\mathrm{Bu}$ yüzden özellikle, özel eğitim alanında çalışan öğretmenlerin Sözleşme'nin engelli çocuklar için öngördüğü hükümlerin yanı sıra tüm çocuklara tanıdığ gerekir. Bu tür bilgilenme ise, özel eğitim öğretmenlerine, hizmet öncesinde, lisans eğitimleri sırasında, çocuk hakları konusunda sunulacak dersler, seminerler, konferanslar vb. yollarla sağlanabilir (Akyüz, 2000; Hammarberg 1997).

Engelli çocukların istismara açık olmalarına ilişkin ortak görüş (Cooke ve Standen, 2002; Morris, 1999; Oosterhorn ve Kendrick, 2000; Paul ve Cawson, 2002) ve bu çocuklar için istismar oranının engelli olmayan çocuklarınkinden yüksek olması gerçeği (Crosse ve diğerleri, 1992; Sullivan ve Knutson, 2000) bu çocuklara öğretmenlik yapan ya da onlara hizmet götüren kişilerin çocuk hakları konusunda bilgilendirilmelerinin önemini gündeme getirmektedir. Engelli çocuklara öğretmenlik yapan ya da onlara hizmet veren kişilerin bu konuda bilgilendirilmeleri hem engelli çocukların istismarını görmezden gelme eğilimini (Cooke ve Standen, 2002) azaltacak hem de öğretmenlerin bu konudaki bilgisizliklerini (Casas ve diğerleri, 2006; Cooke ve Standen, 2002; Karaman, 1993; Shumba, 2003) gidererek, engelli çocukları kendi hakları konusunda bilgilendirme, istismara karşı kendilerini 
korumayı öğrenme vb. konularda öğretmenlerin etkin rol almalarını sağlayacaktır. Osler ve Starkey (1998) çocuk haklarının çocuklara öğretilmesi konusunda okulların anahtar rolüne dikkat çekmiştir. $\mathrm{Bu}$ yazarlara göre, bu tür bir bilgilendirme okul programının bir parçası olarak sağlanmalıdır. Ayrıca okul, insan haklarına saygının sergilendiği bir ortam olarak tüm topluma 1şık tutmalıdır.

Hem okul programını doğrudan aktaran, hem de okul iklimini etkileyen bir kişi olması nedeniyle, öğretmenin de çocuk hakları konusunda eğitiminin gerekliliği ileri sürülebilir. Öğretmenlere bu konuda verilecek eğitimlerde, Çocuk Hakları Sözleşmesi'nin hükümlerinin tartışıldığı tüm bilimsel yayınlardan yararlanılması gerekmektedir. Kuşkusuz, Sözleşme'nin içeriğinin başta öğretmenler olmak üzere okulun tüm öğeleri tarafindan bilinmesi halinde, demokratik tutumların sergilendiği ve şiddetten uzak bir okul ikliminden söz edilebilir (Hammarberg, 1997). Daha önce de belirtildiği gibi, Sözleşme özel gereksinimli çocukları da kapsayan özel durumdaki çocukların korunmasına yönelik hükümler de getirmiştir. Bu çocukların eğitimlerinden sorumlu olan öğretmenlerin, hizmet öncesinde ve hizmet içinde, Sözleşme'nin tüm hükümlerinin yanında özellikle engelli çocuklar ile ilgili hükümleri hakkında bilinçli olmaları gerekmektedir. Özellikle özel eğitim öğretmen adaylarının lisans programlarına çocuk hakları ile ilgili dersler konularak çocuk haklarına duyarlı olmaları sağlanabilir. $\mathrm{Bu}$ yapılamıyorsa, en azından programlarında yer alan derslerin içeriklerinin Çocuk Hakları Sözleşmesi ile ilişkilendirilmesi; ilgili tartışmaların Sözleşme ile desteklenmesi önerilebilir.

Araştırmanın diğer bulgularına bakıldığında, tüm öğrencilerin (ZEÖ, SÖ, OÖÖ ve BÖTE) çocuk haklarına yönelik tutumları ile yaşları arasında olumsuz, düşük ve anlamlı bir ilişkinin olduğu dikkati çekmektedir. Yaşın artışının çocuk haklarına ilişkin tutumları olumlu olarak etkilediği söylenebilir. Diğer yandan, sınıf düzeyinin çocuk haklarına ilişkin tutumlar üzerinde anlamlı bir etkiye sahip olduğu, 4. sınıf öğrencilerinin, 1. sınıf öğrencilerinden çocuk haklarına ilişkin daha olumlu bir tutuma sahip oldukları gözlenmiştir. Bu bulgu 1şığında, çocuk hakları alanındaki eğitimlerin, öğretmenlik lisans programlarının 1. sınıfından başlayacak şekilde sunulmasında yarar olduğu söylenebilir.

Cinsiyet değişkeninin çocuk haklarına ilişkin tutumlar üzerindeki etkisi ele alındığında, hem tüm araştırma grubu hem de insan hakları ya da çocuk haklarına ilişkin ders alan öğrenci grubu için cinsiyetin tutumlar üzerinde etkili olmadığı gözlenmiştir. Bununla birlikte, insan hakları ya da çocuk haklarına ilişkin ders almayanlar için cinsiyetin tutumları farklılaştırdığı, ders almayan öğrenci grubunda, kızların erkeklere göre çocuk haklarına 
ilişkin daha olumlu bir tutuma sahip olduğu dikkati çekmiştir. Bu bulgular ışığında, insan hakları ya da çocuk haklarına ilişkin bir ders almış olmanın, her iki cinsiyet üzerinde de çocuk haklarına ilişkin tutumlar üzerindeki olumlu etkisi bir kez daha görülmüştür.

\section{SONUÇ}

Ankara Üniversitesi Eğitim Bilimleri Fakültesi’nin ZEÖ, SÖ, OÖÖ ve BÖTE Bölümü öğrencilerinin çocuk haklarına ilişkin tutumlarına ilişkin elde edilen veriler ile sınırlı olan bu araştırmada, ZEÖ programına kayıtlı öğrencilerin çocuk haklarına yönelik tutumlarının cinsiyet, sınıf düzeyi ve yaş değişkenlerinden etkilenmediği belirlenmiştir. ZEÖ programına kayıtlı olan öğrenci grubunun çocuk haklarına ilişkin tutumlarının, yalnızca SÖ programına kayıtlı öğrencilerin tutumlarına göre daha olumsuz olduğu belirlenmiştir.

Tüm grup için, çocuk hakları ya da insan haklarına ilişkin ders almanın, son sınıfta okuyor olmanın ve yaşın artmasının çocuk haklarına ilişkin tutumları olumlu olarak etkilediği ortaya çıkmıştır. Diğer yandan, yine tüm grup için cinsiyetin tutumları etkilemediği, yalnızca insan hakları ya da çocuk hakları ile ilgili herhangi bir ders almayan grupta kız öğrencilerin erkek öğrencilere göre çocuk haklarına yönelik daha olumlu bir tutuma sahip olduğu dikkati çekmiştir.

Araştırmanın sonuçlarına dayalı olarak, başta ZEÖ olmak üzere tüm öğretmenlik programlarına çocuk hakları ile ilgili derslerin yerleştirilmesi ya da en azından bu konu ile ilgili derslerin içeriklerinin çocuk hakları temasını da içerecek şekilde zenginleştirilmesi önerilebilir. Buna ek olarak, engelli çocuklara hizmet veren tüm personelin hizmet içi eğitimlerle çocuk hakları konusunda bilinçlendirilmesinde de yarar vardır.

Gelecekte, diğer eğitim fakültelerindeki ZEÖ bölümü öğrencilerinin çocuk haklarına ilişkin tutumlarını, farklı değişkenler açısından ortaya koyacak ileri araştırmalar yapılabilir. 


\section{KAYNAKLAR}

Akyüz, E. (1999). Çocuk hakları ve çocuk hakları eğitimi: Cumhuriyet döneminde eğitim. Ankara: Milli Eğitim Bakanlığı Yayınları.

Akyüz, E. (2000). Ulusal ve uluslararası hukukta çocuğun haklarının ve güvenliğinin korunmast. Ankara: Milli Eğitim Basımevi.

Alderson, P. (2000) Young children's rights: Exploring beliefs, principles and practice. London: Jessica Kingsley Publishers.

Archard, D. (1993) Children rights and childhood. London: Routledge.

Bıyıklı, L. (1997) Özel eğitime gereksinim duyan çocuklar. Milli Eğitim Dergisi, 136, 30-34.

Bloom, B. S. (1995). Insan nitelikleri ve okulda ögrenme. (Çev. D. A. Özçelik), Ankara: Milli Eğitim Basımevi.

Burt, R. A. (1979). Children as victims. In P.A. Vardin, \& Brody, (Eds.), Children's rights, contemporary perspectives. New York: Teachers College Press, Columbia University.

Casas, F., Sapariti, A., González, M., Figuer, C., Rostan, C., Sadurni, M.,Alsinet, C., Gusó, M., Grignoli, D., Mancini, A., Ferucci, F., \& Rago, M. (2006). Children's rights from the point of view of children, their parents and their teachers: A comparative study between Catalonia (Spain) and II Molise (Italy). The International Journal of Children's Rights, 14, 1-75.

Cooke, P., \& Standen, P. J. (2002). Abuse and disabled children: Hidden needs? Child Abuse Review, 11, 1-18.

Covell, K., \& Howe, R. B. (1999). The impact of children's rights education: A Canadian study. The International Journal of Children's Rights, 7, 171-183.

Crosse, S. B., Kaye, E., \& Ratnofsky, A. (1992). A report on the maltreatment of children with disabilities. (Eric Document Reproduction Service No. ED 365 089).

Çağlar, D. (1997) Türkiye'de özel eğitime muhtaç çocuklar. Milli Eğitim Dergisi, 136, 34-38.

Davis, S. M., \& Schwartz, M. D. (1987). Children's rights and the law. Lexington, Massachusetts: Lexington Books, D. C. Heath and Company.

Franklin, B. (2001). New handbook of children's rights: Comparative policy and practice. London: Routledge.

Freeman, M. (2000). The future of children's rights. Children \& Society, 14, 277-293.

Hallett, C. (2000). Children's rights. Child Abuse Review, 9, 389-393.

Hammarberg, T. (1997). A school for children with rights. UNICEF.

Harmandar, M. (1997) Türkiye'de özel eğitim. Milli Eğitim Dergisi, 136, 4041. 
Hart, S. N., \& Pavlovic, Z. (1991). Children's rights in education: An historical perspective. School Psychology Review, 20(3), 345-358.

İnan, A. N. (1995). Çocuk hakları sözleşmesi. A.Ü. Hukuk Fakültesi Dergisi, 1(4), 768-769.

Karaman, Y. (1993). İlkokul ögretmenlerinin gözlemlerine göre çocukların aileleri tarafindan istismarl ve ihmali. Yayınlanmamış yüksek lisans tezi, Hacettepe Üniversitesi, Ankara.

Karaman Kepenekci, Y. (2006). A study of university studets' attitudes towards children's rights in Turkey. The International Journal of Children's Rights, 14, 307-319.

Landsdown, G. (1998). Practice and implementation: The rights of disabled children. The International Journal of Children's Rights, 6, 221-227.

Lansdown, G. (2000). Children's rights and domestic violence. Child Abuse Review, 9, 416-426.

Littlechild, B. (2000). Children's rights to be heard in child protection processes - law, policy and practice in England and Wales. Child Abuse Review, 9, 403-415.

Lundy, L., \& Kilpatrick, R. (2006). Children's rights and special educational needs: Findings

from research conducted fort he Northern Ireland Commissioner for Children and Young People. Support for Learning, 21(2), 57-63.

Morris, J. (1999). Disabled children, child protection systems and the children act 1989. Child Abuse Review, 8, 91-108.

Oosterhorn, R., \& Kendrick, A. (2001). No sign of harm: Issues for disabled children communicating about abuse. Child Abuse Review, 10, 243-253.

Osler, A., \& Starkey, H. (1998). Children's rights and citizenship: Some implications fort he management of schools. The International Journal of Children's rights, 6, 313-333.

Paul, A., \& Cawson, P. (2002). Residential settings: What we know and what we don't know. Child Abuse Review, 11, 262-281.

Rodham, H. (1979). A legal perspective. In P.A. Vardin, \& Brody (Eds.), Children's rights, contemporary perspectives (21-23). New York: Teachers College Press, Columbia University.

Shumba, A. (2003). Children's rights in schools: What do teachers know? Child Abuse Review, 12, 251-260.

Sullivan, P. M., \& Knutson, J. F. (2000). Maltreatment and disabilities: A population-based epidemiological study. Child Abuse \& Neglect, 24(10), 1257-1273.

Wringe, C. A. (1985). Children's rights: A philosophical study. London: Routledge \& Kegan Paul. 